\title{
Opposition to Capital Market Opening
}

Philipp Engler

Alexander Wulff

School of Business \& Economics

Discussion Paper

Economics

$2011 / 17$ 


\title{
Opposition to Capital Market Opening
}

\author{
Philipp Engler $\quad$ Alexander Wulff*
}

21 October 2011

\begin{abstract}
We employ a neoclassical growth model to assess the impact of financial liberalization in a developing country on capital owners' and workers' consumption and welfare. We find in a baseline calibration for an average non-OECD country that capitalists suffer a 42 percent reduction in permanent consumption because capital inflows reduce their return to capital while workers gain 8 percent of permanent consumption because capital inflows increase wages. These huge gross impacts contrast with the small positive net effect found in a neoclassical represent agent model by Gourinchas and Jeanne (2006). We further show that the result for capitalists is insensitive to enhanced productivity catch-up processes induced by capital inflows. Our findings can help explain why poorer countries tend to be less financially open as capitalists' losses are largest for countries with the lowest capital stocks, inducing strong opposition to capital market opening.
\end{abstract}

Keywords: Capital flows, international financial integration, growth, neoclassical model, heterogenous agents

JEL classification: F2, F3, F43, E13, E25, O11

${ }^{*}$ Freie Universität Berlin, Boltzmannstr. 20, 14195 Berlin, Germany, email: philipp.engler@fu-berlin.de and a.wulff@fu-berlin.de. Comments by Moritz Schularick, Thomas Steger, Dominic Quint, Christoph Große Steffen and Wolfgang Strehl are gratefully acknowledged. 


\section{Introduction}

The international integration of financial markets has long been regarded as a panacea for economic development by mainstream economists. In an oftencited paper, Fischer (1998) summarized one of the main hopes associated with cross-border capital flows between developed and less developed countries: Free capital flows would allow an efficient global allocation of savings and thereby increase economic growth and welfare. Another potential benefit is a reduction of consumption volatility because of better diversified portfolio holdings that allow a reduction of exposures to country or industry specific shocks (see Eichengreen and Mussa 1998). These benefits should have been particularly big for developing countries and standard theories predicted huge "downhill" flows of capital, i.e. from rich to poor countries, in order to close the gap of per capita stocks of capital.

However, the fast growing literature of the past few years has shown that most of these promises did not materialize in a significant and robust order of magnitude. In their excellent survey of the literature, Kose et al. (2009) showed that based on aggregate data it is difficult to find robust evidence that financial integration systematically increases economic growth. Furthermore Kose et al. (2003) showed that the ratio of consumption growth volatility to income growth volatility even rose for emerging markets in the recent period of globalization and remained flat for low income developing countries. Even more striking is the finding that the size of capital flows dramatically fails to fit into the picture of standard theories: In his famous article, Lucas (1990) showed that capital flows to developing countries were much too low, a puzzle that has not vanished over time but, to the contrary, became even stronger. Schularick (2006) showed that in the recent period of financial integration capital flows to developing countries were even lower than in the period before World War $\mathrm{I}^{1}$.

In this paper we add to the theoretical debate about potential causes of the last of these stylized facts, the low inflow of capital to developing countries. We focus on the distributional effects of capital market integration and show that it might not be surprising at all that countries do not opt for large inflows of foreign capital because owners of domestic capital take a massive hit to their income. In an otherwise standard neoclassical growth model of a developing country we implement a heterogenous agent approach in order to look at the polar case of complete concentration of the domestic capital stock in the hands of a few capitalists. Their only income derives from the

\footnotetext{
${ }^{1}$ Prasad et al. (2006) even showed that since the mid 1990's there is a tendency of capital to flow "uphill", which means from poor to rich countries.
} 
returns to their stock of capital while workers receive only wage income. We show in a benchmark calibration that capitalists suffer a permanent decrease in consumption of 42 percent when capital flows in, more than doubling the capital stock. Workers, on the other hand, gain as the higher stock of capital increases wages by 8 percent.

Our motivation to go beyond the single representative agent approach and to assume a completely unequal distribution of wealth and income is based on poverty line data of developing countries. According to the World Bank's World Development Indicators $\&$ Global Development Finance database, in the developing countries of Sub-Saharan Africa and East Asia \& Pacific the fraction of the population with no more than $\$ 2(\mathrm{PPP})$ a day in 2005 are 72,9 $\%$ and $38,7 \%$ respectively. This clearly implies that savings of that part of the population cannot be of a remarkable order of magnitude and consequently, main parts of the domestic capital stock are held by a small group of capital owners. $^{2}$

Our result that financial integration has enormous distributional effects and especially that domestic capital owners will suffer implies that consequences for policies with respect to capital flows are to be expected. Even though our model, like any standard theory, suggests that for countries as a whole there are gains from integration and that Pareto improvements are possible if re-distributional institutions are in place, our result suggests that the huge amount of transfers that are necessary to leave no one worse off is simply too big to achieve for most countries so that opposition to inflows is likely to be pervasive on the side of capital owners. And this opposition can be expected to be the larger the poorer a country is as losses are the bigger the poorer a country is.

An indication that such concerns on the side of capitalists in less developed countries are indeed relevant is that the strongest restrictions to capital flows can be found among these countries. Figure 1 shows the Chinn-Ito index of capital market openness ${ }^{3}$ and the respective GDP per capita (PPP) for 170 countries in $2008^{4}$. This index increases with the degree of openness and one can see that the severest restrictions can be found among the countries with less than US-\$16000 per capita GDP. Above this threshold there

\footnotetext{
${ }^{2}$ To the best of our knowledge, direct evidence on wealth distributions is not available for developing countries.

${ }^{3}$ The Chinn-Ito index measuring the extensity of capital controls is based on information of the IMF's Annual Report on Exchange Arrangements and Exchange Restrictions (see Chinn and Ito (2008) for details).

${ }^{4}$ These are all countries for which both variables are available. For GDP data, we again use the World Bank's World Development Indicators \& Global Development Finance database.
} 


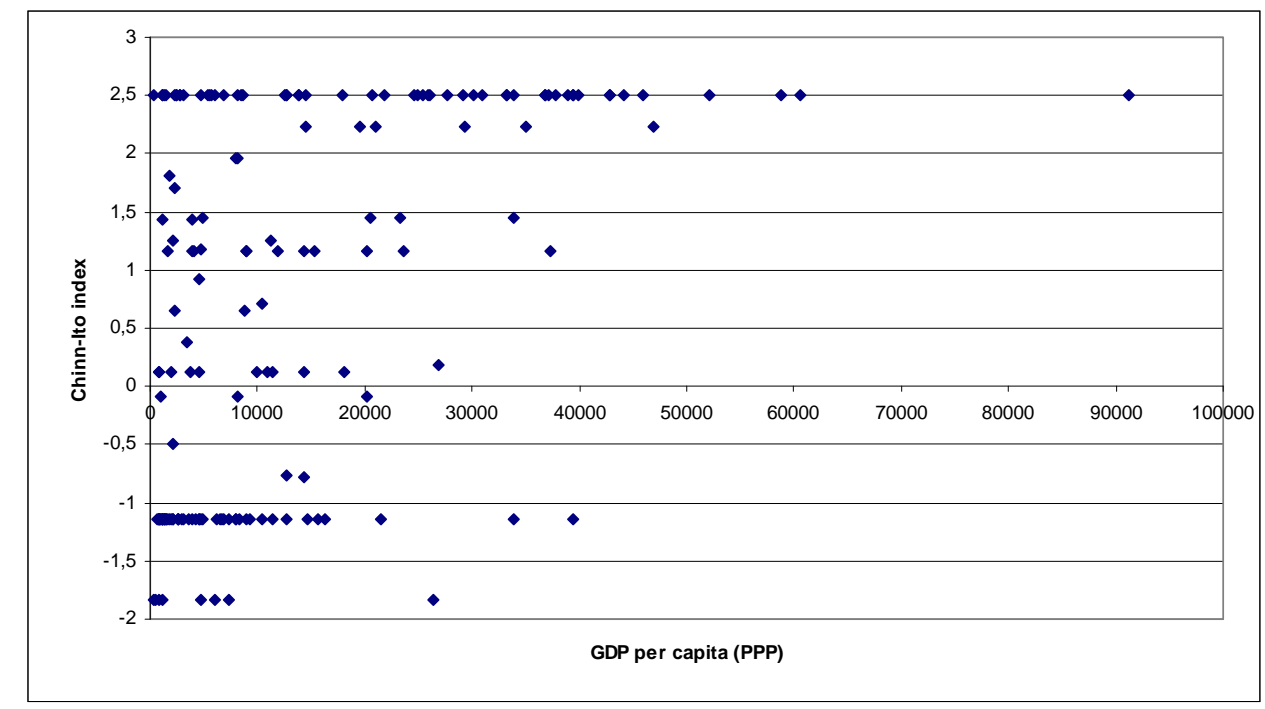

Figure 1: Capital market openness and GDP per capita (PPP)

are hardly countries in the lower part of this graph. Our results can also contribute to explanations of the findings of Reinhardt et al. (2010) that in countries with a closed capital account there is no systematic relationship between net capital flows and the level of development.

The analysis of the sign of the gross effects for different groups of society are not novel to the literature. Our approach mostly refers to the work of Alfaro (2004), Pinto (2005), Pinto and Pinto (2008) and Aizenman (2005). Alfaro shows in an overlapping generation model that in a capitalimporting country old people (capitalists) who only receive capital income would vote against capital account liberalization while young people (workers) would prefer to remove capital flow barriers. Results are of opposite sign for a capital-exporting country. Furthermore the author shows that these patterns are consistent with data on liberalization policies. Pinto (2005) comes up with similar results by looking at the influence of FDI: Labor favors foreign direct investment due to its positive effect on the wage rate while capital suffers under the downward pressure of FDI on the interest rate. This means that governments, supporting workers' interests will welcome foreign investors while governments supporting capitalists' interests will try to keep FDI out. In an empirical analysis, Pinto shows that when in power pro-labor parties are more likely to adopt policies that support the interests of labor. In Pinto and Pinto (2008) the interaction of partisanship and FDI is enriched by a sectoral analysis. In Aizenman (2005) FDI in terms of "green-field" in- 
vestments also have a negative impact on the domestic capitalists' welfare: The increased wage rate reduces the return on domestic capital ${ }^{5}$.

This literature did not calculate the size of the distributional effects of capital market integration and this is what we do in this paper. Regarding our calibration approach a strong connection exists to the work of Gourinchas and Jeanne (2006; G\&J in what follows). Employing a standard neoclassical growth model in the tradition of Ramsey-Cass-Koopmans where only a representative agent who earns capital and labor income exists, the authors show that a capital scarce country only gains $1.7 \%$ of permanent consumption even though the capital stock more than doubles due to foreign capital inflows. The comparison between these results and ours is of interest given that the former represents the overall net gain of an economy due to financial integration while the latter separates the gross effects on income for different groups of society.

The following is structured as follows: Section 2 presents the model setup with two types of agents, capitalists and workers, for two scenarios, one of a financially closed and one of a financially integrated developing economy. Section 3 describes for a calibrated version of the model the differential impact of financial openness for consumption and welfare relative to the autarky scenario for capitalists and workers and discusses the impact of a productivity catch-up process which may be induced by financial inflows. Section 4 concludes.

\section{The Model}

In order to measure the distributional effects of financial globalization for poor countries, we assume that the economy is populated by two types of agents, capital owners and workers. Without loss of generality we normalize the population of capital owners to one and assume a number of $L$ identical workers. Therefore the ratio of capital owners to workers is given by $\eta=1 / L$ which is, by assumption, constant over time. The capitalist does not work but receives income from the returns to his stock of capital. Workers supply their labor to a domestic firm and only receive wage income.

In order to compare the effects of foreign capital inflows we analyse two scenarios, a baseline scenario without financial integration, i.e. financial autarky, and a scenario in which free capital flows are allowed. In the first one there are no international capital flows at all and therefore the development

\footnotetext{
${ }^{5}$ However, the opportunity to sell equity can increase the capitalists' welfare in the presence of borrowing constraints. In this case, domestic capitalists may agree with equity market opening.
} 
of the domestic stock of capital is completely determined by the capitalist's savings. In the second one the capitalist is allowed to borrow and lend freely on an international capital market at an exogenously given interest rate $R^{*}$.

The capitalist's and the representative worker's period utilities are given by the log-function, so that their objective functions are

$$
U_{c}=\sum_{t=0}^{\infty} \beta^{t} \ln \left(c_{t}^{c}\right)
$$

and

$$
U_{w}=\sum_{t=0}^{\infty} \beta^{t} \ln \left(c_{t}^{w}\right)
$$

respectively where $\beta$ is the discount factor which is constant over time and the same for both groups, and where $c_{t}^{c}$ and $c_{t}^{w}$ are the capitalist's and the worker's period $t$ consumption per capita.

Workers offer one unit of labor and consume their entire wage income so that the representative worker's budget constraint is

$$
c_{t}^{w} \leq w_{t}
$$

where $w_{t}$ is the wage rate. While this constraint is independent of the scenario, the capitalist's budget constraint differs across scenarios and will be introduced below.

A single good is produced by a firm employing the input factors capital and labor. Technology is given by a Cobb-Douglas production function of the form

$$
Y_{t}=K_{t}^{\alpha}\left(A_{t} L_{t}\right)^{1-\alpha}
$$

where $Y_{t}$ is the output of the single good, $A_{t}$ is a labor-augmenting measure of productivity, $K_{t}$ the stock of capital and $L_{t}$ labor. Labor productivity grows at rate $g_{t+1}=\frac{A_{t+1}}{A_{t}}-1$ which may differ across countries in the short run, but which is the same for all countries in the long-run (see for a discussion G\&J).

In order to induce stationarity we define

$$
\widetilde{y}_{t} \equiv \frac{Y_{t}}{A_{t} L_{t}}=\widetilde{k}_{t}^{\alpha}
$$

as the output per effective labor input. Factor markets are perfectly competitive so that labor and capital are paid their marginal products:

$$
\begin{aligned}
& R_{t}=1+\alpha{\widetilde{k_{t}}}^{\alpha-1}-\delta \\
& w_{t}=A_{t}(1-\alpha){\widetilde{k_{t}}}^{\alpha}
\end{aligned}
$$

where $R_{t}$ is the gross real domestic interest rate and $\delta$ the depreciation rate. 


\subsection{The baseline scenario}

In the baseline scenario the capitalist and workers maximize their utility functions (1) and (2). The worker only maximizes with respect to consumption given the constraint (3) resulting in a level of consumption equal to the level of wage income. The capitalist maximizes subject to the constraint

$$
c_{t}^{c}+k_{t+1}^{c} \leq R_{t} k_{t}^{c}
$$

with respect to consumption $c_{t}^{c}$ and capital per capita (i.e. per capitalist) $k_{t+1}^{c}$, given $k_{0}^{c}$ and subject to a transversality condition. In this scenario capital is the only asset available to the capitalist.

From the first order conditions of the capitalist's maximization problem we get the consumption Euler equation

$$
\widetilde{c}_{t+1}^{c}=\frac{1}{1+g_{t+1}} \beta R_{t+1} \widetilde{c}_{t}^{c}
$$

where the tilde indicates normalization with productivity, i.e. $\widetilde{c}_{t}^{c} \equiv c_{t}^{c} / A_{t}$. Given logarithmic utility, the income and the substitution effects cancel each other out which allows to write an explicit expression for the optimal choices of $\widetilde{c}_{t}^{c}$ and $\widetilde{k}_{t+1}^{c}{ }^{6}$ :

$$
\begin{aligned}
\widetilde{k}_{t+1}^{c} & =\frac{1}{1+g_{t+1}} \beta R_{t} \widetilde{k}_{t}^{c} \\
\widetilde{c}_{t}^{c} & =(1-\beta) R_{t} \widetilde{k}_{t}^{c}
\end{aligned}
$$

Capital owners thus save and consume a constant fraction of their income in each period.

Given that within groups agents are homogenous we can determine the relationship between $\widetilde{k}_{t}^{c}$ and the capital stock per efficient unit of labor $\widetilde{k_{t}}$ :

$$
\widetilde{k}_{t}^{c}=\frac{K_{t}}{\eta A_{t} L_{t}}=\frac{1}{\eta} \widetilde{k_{t}}
$$

The introduction of heterogeneity in the model thus allows scenarios in which a developing country can be capital scarce in terms of capital per worker but where capital owners themselves can nevertheless be rich in terms of capital per capitalist. However, in our analysis which follows in section 3 we are only concerned with effects of financial integration measured in relative terms, so that $\eta$ plays no further role.

\footnotetext{
${ }^{6}$ See Appendix A.1.
} 
As is known from standard neoclassical growth models, the economy converges toward a steady state where

$$
R^{*}=\frac{1+g^{*}}{\beta}
$$

and the capital stock per efficient unit of labor is given by

$$
\widetilde{k}^{*}=\left(\frac{R^{*}-1+\delta}{\alpha}\right)^{\frac{1}{\alpha-1}}
$$

whereas in per capitalist terms

$$
\widetilde{k}^{* c}=\frac{1}{\eta} \widetilde{k}^{*}
$$

\subsection{Free capital flows}

We now turn to the scenario of perfect financial integration where crossborder capital flows are unrestricted. In contrast to the case of financial autarky, domestic capital owners are now allowed to borrow and lend at a given gross real interest rate $R^{*}$. Following G\&J we assume the world interest rate to be equal to the autarky steady state interest rate. This implies that under financial integration the long-run domestic stock of capital per worker and therefore production per worker are the same as under autarky. In addition, this assumption assures that the capitalist's normalized consumption and asset holdings are constant in the steady state. (see for a general discussion Barro and Sala-i-Martin, 2004).

The opportunity to lend and borrow at the world capital market basically means that assets per capitalist can differ from capital per capitalist. We therefore define $d^{c}$ as the domestic capital owner's net debt to foreigners, so that the budget constraint is now

$$
c_{t}^{c}+k_{t+1}^{c}+R_{t}^{*} d_{t}^{c} \leq R_{t} k_{t}^{c}+d_{t+1}^{c}
$$

The problem of the representative capitalist is given by maximizing (1) s.t. (6) given $k_{0}^{c}, d_{0}^{c}$ and a no-Ponzi game condition. In order to start with the same initial condition in both scenarios we assume that the option to lend or borrow at the world capital market is possible in period 0 for the first time implying $d_{0}^{c}$ to be zero. From the first order conditions we now have

$$
R^{*}=R_{t+1}
$$


and

$$
\widetilde{c}_{t+1}^{c}=\frac{1}{1+g_{t+1}} \beta R^{*} \widetilde{c}_{t}^{c}
$$

The free cross-border capital flows thus imply that the domestic return on capital is equal to the world interest rate. This additionally implies that the capital stock per efficient unit of labor jumps immediately to its long-run steady state level given by equation (5), regardless of the preferences of the domestic capital owner. Equation (8) is again the Euler equation but now in the scenario of free capital flows. Using the result (7) and defining $a_{t}=k_{t}-d_{t}$ $\forall t$ as the capitalist's own assets we again get explicit expressions for optimal normalized asset holdings and consumption. For $t>0$ we have ${ }^{7}$

$$
\begin{aligned}
\widetilde{a}_{t+1}^{c} & =\frac{1}{1+g_{t+1}} \beta R^{*} \widetilde{a}_{t}^{c} \\
\widetilde{c}_{t}^{c} & =(1-\beta) R^{*} \widetilde{a}_{t}^{c}
\end{aligned}
$$

Given that $R^{*}$ equals the common long-run steady state interest rate, consumption and savings per capita of the representative capital owner grow at rate $g^{*}$ immediately after financial integration.

\section{Effects of financial integration}

We now employ the model to quantify the effects of capital market opening for capitalists and workers. After an outline of the calibration we start with the discussion of the effects of financial integration for both groups. We therefore introduce and use two metrics of welfare: The first one compares the discounted present value of utility under autarky and under capital market openness for the two respective groups. That allows us to demonstrate the development of the consumption and welfare gap in every single period in order to give an intuition for our simulation results that follow. A gap is defined as the difference of a variable's realization in both scenarios. To aggregate the period per period results we then simulate the permanent percentage change in consumption that brings welfare under autarky to its level under financial integration. This indicator allows us to quantify the effects of capital mobility in terms of average consumption change.

\footnotetext{
${ }^{7}$ In period 0 when capital flows are not allowed yet we have $\widetilde{a}_{1}^{c}=\frac{1}{1+g_{1}} \beta R_{0} \widetilde{a}_{0}^{c}, \widetilde{c}_{0}^{c}=$ $(1-\beta) R_{0} \widetilde{a}_{0}^{c}$ with $\widetilde{a}_{0}^{c}=\widetilde{k}_{0}^{c}$ and $R_{0}$ given (see Appendix A.2 for details).
} 


\subsection{Calibration}

In our calibration we stay close to the analysis of G\&J in order to allow for a direct comparison with their results. We use the following values for the model parameters:

\begin{tabular}{|c|c|c|c|}
\hline$\alpha$ & $\beta$ & $\delta$ & $g^{*}$ \\
\hline 0.3 & 0.96 & 0.06 & 0.012 \\
\hline
\end{tabular}

These parameter values imply a long run interest rate of 1.0542. Furthermore we assume that productivity grows with the rate $g^{*}$ from year 0 onwards.

In addition to the parameter values we also have to determine the initial conditions regarding the capital stock in period 0 . This value plays an important role because, as we will show in the next section, the greater the gap between the initial capital stock per worker and the capital stock that would be reached if the economy immediately jumps to its steady state, the stronger the effects of free capital flows will be. G\&J calculate the initial capital to output ratio by using data of 82 non-OECD countries in the year 1995. They find a population weigthed average capital to output ratio of 1.4. This corresponds to a capital stock that is roughly 41 percent of the capital stock in the steady state if it were reached immediately. ${ }^{8}$ This means that the average non-OECD country starts with less than half of the capital stock per worker which would be reached under financial integration in that period. The average ratios in the top and the bottom decile are 0.25 and 0.73 respectively.

\subsection{Capitalists}

The sign of the effect of integration for the capitalist's welfare is easily explained. We know from the first order conditions of the representative capital owner that the domestic return to capital and the world interest rate are equal under financial integration so that there exist no arbitrage opportunities in equilibrium. But without opportunities for arbitrage profits, the only effect on the capitalist's income in a capital-importing country is the negative effect of the increased capital stock on the interest rate. Therefore, domestic capitalists in a developing country will be worse off in the case of financial integration.

$$
{ }^{8} k_{0} / k^{*}=\left(\frac{k_{0} / y_{0}}{k^{*} / y^{*}}\right)^{\frac{1}{1-\alpha}}=0.41 \text { with } k^{*} / y^{*} \text { of } 2.63 .
$$


To see how this effect works, we have a look at the capitalist's savings in the first period where cross-border capital flows are allowed. Given that these are always a constant fraction of his income which is the same in both scenarios in that period, we know that savings remain unchanged at the same level as under autarky ${ }^{9}$. But given that the capital stock immediately jumps up to its steady state level and recalling that $d_{1}^{c}=k^{*}-a_{1}^{c}$ it is clear that if the capitalist's savings are not sufficient, the additional amount will be borrowed on the world capital market $\left(d_{1}^{c}>0\right) .{ }^{10}$ This simply means that in the next period the capital owner possesses the same amount of assets as under autarky but derives a lower income from these assets because of the reduced interest rate.

In order to assess the differential income effects under autarky and financial integration in the following periods, we calculate the difference of the capitalist's welfare in the two scenarios. We therefore define

$$
W_{\text {loss }}^{c}=U_{c}^{A}-U_{c}^{I}=\sum_{t=0}^{\infty} \beta^{t} U\left(c_{t}^{c A}\right)-\sum_{t=0}^{\infty} \beta^{t} U\left(c_{t}^{c I}\right)
$$

where $W_{\text {loss }}^{c}$ is the difference in welfare under autarky $U_{c}^{A}$ and under financial integration $U_{c}^{I}$. Using $c_{t+j}^{c A}=(1-\beta) \beta^{j} \prod_{i=0}^{j} R_{t+i} k_{t}^{c}$ and $c_{t+j}^{c I}=(1-$ $\beta) \beta^{j}\left(R^{*}\right)^{j} R_{t} k_{t}^{c}$ whereby $c^{c A}$ and $c^{c I}$ denote consumption under autarky and under financial integration respectively, we get ${ }^{11}$

$$
W_{\text {loss }}^{c}=\sum_{t=0}^{\infty} \beta^{t} \ln \left(\frac{\prod_{j=1}^{t} R_{j}}{\left(R^{*}\right)^{t}}\right)
$$

Equation (9) thus allows us to track the effects of financial integration for consumption and welfare in every single period. The ratio of consumption of both scenarios in every period is expressed by the respective term in brackets, which is the ratio of the cumulative interest rate under autarky to the cumulative interest rate under financial integration. Given log-utility there is neither a difference in consumption nor in welfare in period 0 . In the following periods the negative effects of financial integration on the capitalist's

\footnotetext{
${ }^{9} a_{1}^{c}=\beta R_{t} k_{0}^{c}$.

${ }^{10}$ See Broner and Ventura (2010) for similar results in an overlapping generations model.

${ }^{11}$ See Appendix A.3.
} 
income take place and cause the consumption gap to increase over time, albeit at a decreasing rate. This can easily be seen because the interest rate under autarky is larger than under financial integration as long as the economy under autarky is on its transitional path. In the steady state where the domestic return to capital is equal to the world interest rate the ratio of consumption of both scenarios becomes constant.

Furthermore the expression for relative consumption clarifies that losses are the larger the poorer the country initially is because the lower the given capital stock in period 0 , the larger is the gap between the interest rates in both scenarios.

The property of the consumption gap to increase over time until the steady state is reached also means that the utility loss in each period grows. However, welfare is evaluated in period 0 so that this effect is partially alleviated by the capitalist's discounting. Given that the consumption gap stays constant in the steady state, the welfare effect of periods in the long-run converges to zero.

Based on the theoretical discussion of these effects we now quantify them. We therefore simulate the percentage change in consumption under autarky which is necessary to equalize welfare of both scenarios in every period. According to equation (9) we know that consumption under autarky will be higher than consumption under financial integration and therefore the change in consumption has to be interpreted as the percentage decrease of consumption under autarky that equalizes welfare of both scenarios.

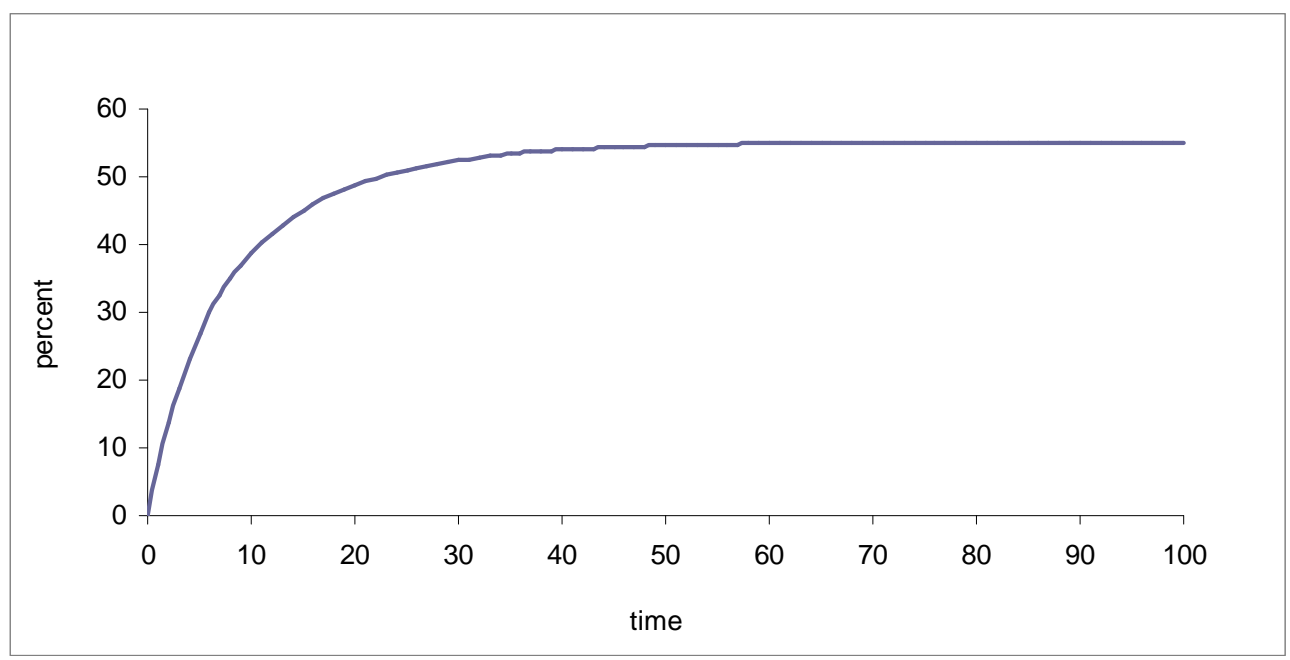

Figure 2: Capitalist's consumption loss (in \%) 
Figure 2 shows the results for the typical non-OECD country for which the initial conditions discussed above apply. As explained, no reduction in consumption is needed in period 0 . However, in the first period after capital flows have increased the domestic stock of capital, the required percentage decrease in consumption that is needed to avoid a loss in welfare under integration relative to autarky is roughly $8 \%$. In the following periods the gap increases but at a decreasing rate. In the fourth period after financial integration a reduction in consumption under autarky of $27 \%$ is needed. The highest value, which is reached in the steady state, is $55 \%$. This result illustrates that capital market integration has very strong negative effects for capitalists of a typical non-OECD country.

We now turn to our second metric of welfare and calculate, in the same vein as G\&J, the permanent change in consumption $\mu_{c}$ which reduces welfare under autarky to its level under financial integration:

$$
\sum_{t=0}^{\infty} \beta^{t} \ln \left(c_{t}^{c A}-\mu_{c} c_{t}^{c A}\right)=U_{c}^{I}
$$

Solving for $\mu_{c}$ we get $^{12}$

$$
\mu_{c}=1-\exp \left((1-\beta)\left(U_{c}^{I}-U_{c}^{A}\right)\right)
$$

This expression has the advantage to express the total effects of financial integration with the help of a single indicator. For the average non-OECD country $\mu_{c}$ is $42 \%$. This means that in a typical developing country, a permanent reduction of the representative capitalist's consumption of $42 \%$ is needed to equalize welfare of both scenarios. In other words, domestic capital owners would spend roughly half of their consumption in order to avoid the reduction of capital control barriers.

Lastly, we want to illustrate the sensitivity of this result with respect to changes in the initial capital stock. Figure 3 presents realizations of $\mu_{c}$ for different initial capital stock ratios, starting with the ratio of the poorest countries of the sample of non-OECD countries and ending with the ratio of the richest countries:

The figure shows that the poorest countries, starting with an initial capital stock per worker of one quarter of the stock under financial integration, the permanent consumption change is $57 \%$. $\mu_{c}$ then falls to its lowest value of $16 \%$ which is the loss for domestic capitalists in a country starting with a relative capital stock of $75 \%$. For the poorest countries these losses to capitalists thus constitute a huge obstacle to financial market opening policies.

\footnotetext{
${ }^{12}$ See Appendix A.5 for details.
} 


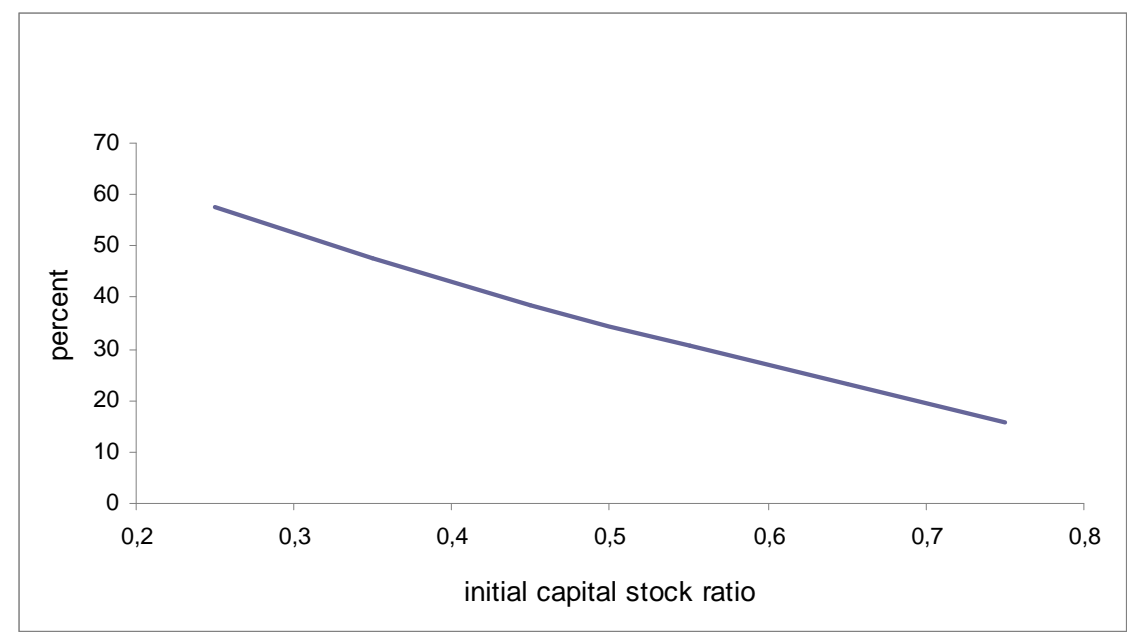

Figure 3: Capitalist's permanent consumption loss after liberalization, $\mu_{c}$, as a function of initial capital stock relative to steady state (in \%)

\subsection{Workers}

The winners of free cross-border capital flows are workers. They benefit from the higher stock of capital which raises the wage rate above the autarky level. In analogy to the analysis for capitalists, we describe the effects for consumption and welfare by defining the difference in welfare under financial integration and under autarky ${ }^{13}$ :

$$
\begin{aligned}
W_{\text {gain }}^{w} & =U_{w}^{I}-U_{w}^{A}=\sum_{t=0}^{\infty} \beta^{t} U\left(c_{t}^{w I}\right)-\sum_{j=0}^{\infty} \beta^{j} U\left(c_{t}^{w A}\right) \\
& =\sum_{t=1}^{\infty} \beta^{t} \ln \left(\left(\frac{k_{1}^{I}}{k_{1}^{A}} \frac{\left(R^{*}\right)^{(t-1)}}{\prod_{j=1}^{t-1} R_{j}}\right)\right.
\end{aligned}
$$

The terms in brackets express the ratio of consumption in both scenarios. This ratio corresponds to the outputs per worker which in turn are determined by the capital stock per worker which is determined by the development of the respective cumulative interest rate. $k_{1}^{I}\left(k_{1}^{A}\right)$ denotes the capital stock per worker under financial integration (autarky) in period 1.

${ }^{13}$ See Appendix A.4. 


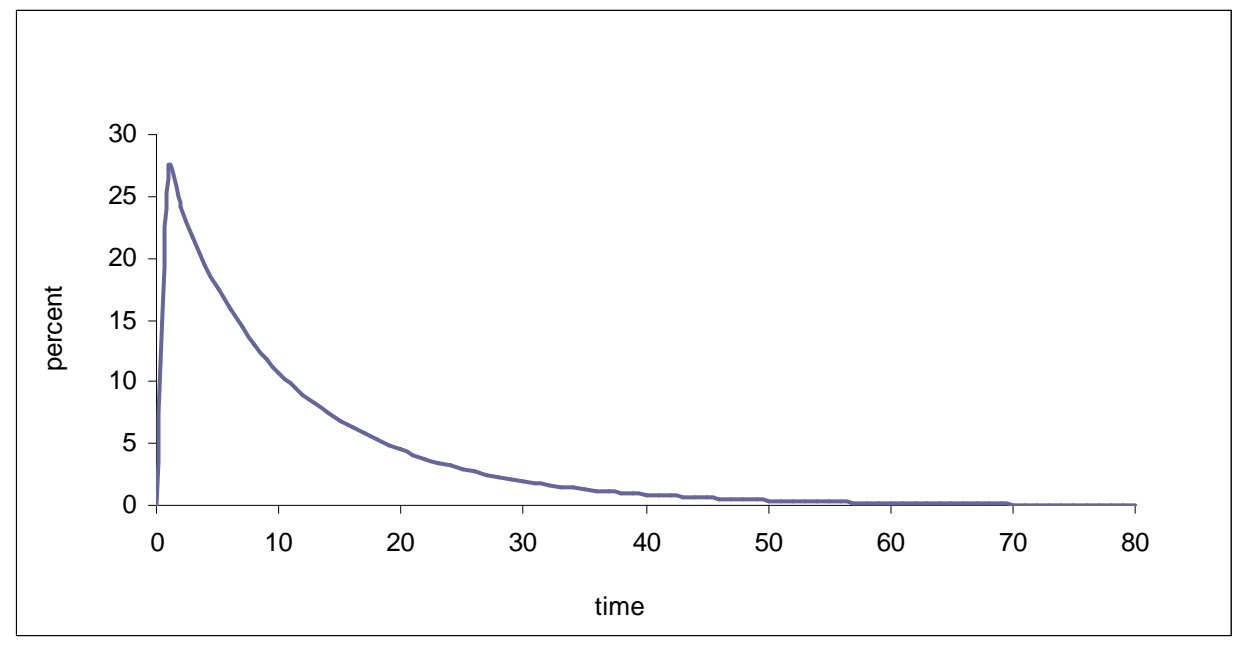

Figure 4: Worker's consumption gain (in \%)

Because the initial capital stock in period 0 is equal in both scenarios there is no difference in consumption in that period. The differing developments of consumption start in the first period after financial integration where the gap peaks. In the following periods the capital stock per worker increases faster in the scenario with no capital inflows than in the case of financial integration, implying the difference in consumption to decrease. This behavior can be seen by the terms in brackets where the interest rate in the case of financial integration is lower than the domestic interest rate under autarky. In the steady state, where capital stocks are equal in both scenarios the consumption gap is zero.

Turning from consumption to welfare, one can see that also the welfare gap peaks in the first period after financial integration. As described above the differences in consumption shrink in the following periods so that weighted with the discount factor the difference in welfare decreases in the future and converges to zero in the long-run.

To quantify the effects just described we now simulate the percentage consumption change that equalizes welfare of both scenarios in each period (Figure 4), i.e. how many percent of consumption under autarky the worker needs to gain to make him just as well off as under openness. We assume the same initial conditions for the average non-OECD country as above.

Figure 4 shows that the percentage difference in consumption for workers is the highest in the first period after financial integration where it jumps to $27.2 \%$. Thereafter the economy under autarky closes the gap to the 
steady state in which the economy under financial integration already is. Ten periods after the opening the difference is still about $11 \%$ while in the steady state, of course, the gap is zero. The comparison between these results and those of the capitalist shows the differing dynamics caused by financial integration: While the workers' gain becomes smaller over time the capitalists' loss increases.

In the next step we calculate the permanent percentage increase in consumption under autarky which equalizes welfare under both scenarios, $\mu_{w}$. Knowing that workers gain in the case of free capital flows we have

$$
\sum_{t=0}^{\infty} \beta^{t} \ln \left(c_{t}^{w A}+\mu_{w} c_{t}^{w A}\right)=U_{w}^{I}
$$

so that we get

$$
\mu_{w}=\exp \left((1-\beta)\left(U_{w}^{I}-U_{w}^{A}\right)\right)-1
$$

where $U_{w}^{A}\left(U_{w}^{I}\right)$ is the worker's welfare under autarky (integration). Again starting with an initial capital ratio of 0.41 , the percentage permanent increase in consumption is $8 \%$ which is significantly lower than the value of the capitalist's loss.

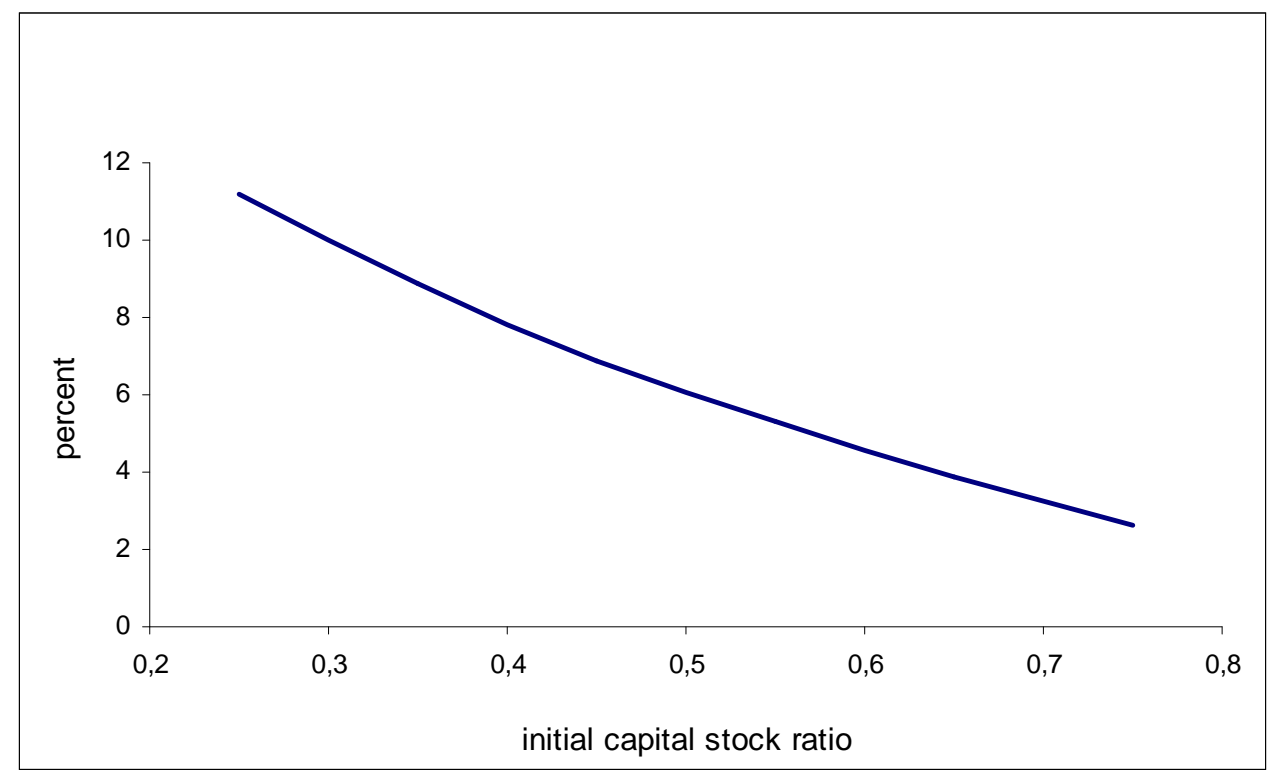

Figure 5: Worker's permanent consumption gain after liberalization, $\mu_{w}$, as a function of initial capital stock relative to steady state (in \%) 
Figure 5 shows the sensitivity of $\mu_{w}$ with respect to variations of the initial conditions for the group of the 82 non-OECD countries: For the poorest countries in that group the permanent consumption change is $11.2 \%$ and $2.6 \%$ for the richest.

The simulation results of the capitalist's loss and the worker's gain show that financial integration has an enormous influence on consumption and thereby welfare. The effects are dramatically larger than in the homogenous agent approach of G\&J where the permanent consumption gain is just 1.74 $\%$. This comparison illustrates that even though the economy wide net effect may be rather small, financial integration can create enormous gross effects.

\subsection{Could a productivity catch-up process help the capitalists?}

Apart from the direct effects capital inflows are also associated with an impact on productivity (see for a discussion for example Hoxha et al., 2009 ${ }^{14}$ ). In order to quantify the influence of a change in the growth rate of productivity G\&J calculate the permanent percentage increase in consumption associated with a productivity catch-up process. They show that in contrast to the influence of capital inflows, the effects caused by a productivity catch-up process are dramatically larger. For example, a typical developing country which opens up to capital inflows and starts with a technological level of roughly one quarter relative to the US, gains $61 \%$ in terms of annual consumption if the productivity gap is reduced by $25 \%$ (relative to the US). This clearly shows that productivity catch-up effects dominate the effects of even large capital inflows.

Turning to the impact of a change in the productivity growth rate in our setting, we are interested in whether such a process could help reduce the capitalist's loss. In order to see how our previous results may change, we assume that financial integration causes $g_{1}$ to be larger than $g^{*}$ which implies a relatively higher level of $A_{1}$. To discuss the effects regarding the capitalist's income and consumption we first look at the behavior of the rate of interest. In general, an increase in productivity raises the marginal product of capital and thereby the interest rate, but the crucial point is that under financial integration the condition

$$
R_{1}=R^{*}
$$

still holds in equilibrium. Given that the world interest rate is not affected by a change in the level of the domestic productivity the initial increase in the

\footnotetext{
${ }^{14}$ See also Baldwin et al. (2005) and Borensztein et al. (1998) for a positive impact and Carkovic and Levine (2005) for a negative one.
} 
domestic interest rate caused by the increase in productivity is completely offset by the increase in the capital stock which is necessary to bring the interest rate down to the world interest rate level. This means that no higher return is paid in period 1 relative to the case where $g_{1}$ is equal to $g^{*}$.

Additionally, we know that savings are always a constant fraction of income which is not affected by a higher value of $A_{1}$ in period 0 . This means, the domestic capitalist will save the same amount as in the previous case and as a consequence, the increased capital stock per capitalist in the next period, which is given by

$$
k_{1}^{c}=A_{1} \widetilde{k}^{* c}=A_{1} \frac{1}{\eta}\left(\frac{R^{*}-1+\delta}{\alpha}\right)^{\frac{1}{\alpha-1}}
$$

is completely financed by an increase in foreign debt

$$
d_{1}^{c}=k_{1}^{c}-a_{1}^{c}
$$

We can thus state a very strong result: A productivity catch-up process which may be caused by financial integration will not reduce the consumption and welfare losses of the domestic capital owners. For policymakers this implies that no reduction in the capitalist's effort to defend capital control barriers can be expected. ${ }^{15}$

\section{Conclusion}

The principal purpose of this paper is to show that financial integration has enormous effects on consumption and welfare if capital and labor income is split between different groups of society. One of our main findings is the dramatic loss of $42 \%$ of permanent consumption for domestic capitalists, contrasting with the relatively small net effects of free cross-border capital flows.

Of course, the complete polarization we present in our model is a very strong assumption, just like one of a perfectly homogenous agent in the standard approach, but it emphasizes the importance of distributional effects and demonstrates the limited power of financial integration to increase overall welfare. Therefore it adds to the debate about why financial integration has not delivered the main promises associated with it yet. We are aware of a trend towards more capital market opening (see Kose et al. 2009), but as

\footnotetext{
${ }^{15}$ Of course, domestic workers will benefit from these catch-up effects due to the increase in the wage rate $w_{1}=A_{1}(1-\alpha) \widetilde{k}^{\alpha}$.
} 
Figure 1 has shown even today there is still a great number of poor countries with tight capital controls.

The simplicity of our framework makes it vulnerable to the critique of a too speedy rate of convergence which is a well-known weakness of standard neoclassical growth models (e.g. Hoxha et al., 2009 and Barro and Sala-i-Martin, 2004). Hoxha et al. (2009) therefore estimate the implied autarky path of convergence of rates of return from actual data and show in a homogenous agent approach that welfare gains are substantially bigger if the speed of convergence is calibrated more realistically. Things would also change in our setting, given that a slower rate of convergence would increase the worker's gain and reduce the capitalist's relative loss in the first periods. However, in the long-run results would be the same and the order of magnitude of our results clearly shows that the distributional effects of financial integration play an important role in the ongoing debate of effects of cross-border capital flows.

Another important point is that our approach provides a rationale for why many countries do not benefit from productivity catch-up processes. Productivity growth which is regarded as one of the main sources of economic growth (see Hall and Jones, 1999) and associated with capital inflows does not reduce the negative influence of financial integration on the capitalist's consumption loss. Thus, the incentive to oppose a capital market opening is not eliminated.

Institutions to re-distribute the gains in net production which arise due to financial integration could solve the capitalists' problem but their implementation may be hard to achieve in any political process. Nevertheless, there should be a stronger focus on the optimal characteristics of such institutions and how they could be introduced. 


\section{References}

[1] Aizenman, J. (2005):" Opposition to FDI and Financial Shocks ", Journal of Development Economics, 77, 467- 476.

[2] Alfaro, L. (2004): "Capital Controls: A Political Economy Approach", Review of International Economics 12, 4, 571-590.

[3] Baldwin, R., H. Braconier and R. Forslid (2005): "Multinationals, Endogenous Growth, and Technological Spillovers: Theory and Evidence", Review of International Economics 13, 945-963.

[4] Barro, R. J. and X. Sala-i-Martin (2004): Economic Growth, MIT Press: Cambridge, Massachusetts, London, England, 2nd edition.

[5] Borensztein, E., J. De Gregorio and J.-W. Lee (1998): "How Does Foreign Direct Investment Affect Economic Growth?", Journal of International Economics 45, 115-135.

[6] Broner, F.A. and J. Ventura (2010): "Rethinking The Effects Of Financial Liberalization", NBER Working Paper No.16640.

[7] Carkovic, M. and R. Levine (2005): "Does Foreign Direct Investment Accelerate Economic Growth?", in: T. H. Moran, E. M. Graham and M. Blomström (eds), Does Foreign Direct Investment Promote Development?, Institute for International Economics, Washington, 195-220.

[8] Chinn, M.D. and H. Ito (2008): "A New Measure of Financial Openness", Journal of Comparative Policy Analysis Vol.10 No. 3, 309-322.

[9] Eichengreen, B. and M. Mussa with G. Dell'Ariccia, E. Detragiache, G. M. Milesi-Ferretti and A. Tweedie (1998): "Capital Account Liberalization: Theoretical and Practical Aspects", IMF Occasional Paper No. 172, Washington, DC, 1998.

[10] Fischer, S., R. N. Cooper, R. Dornbusch, P. M. Garber, C. Massad, J. J. Polak, D. Rodrik and S. S. Tarapore (1998): "Should the IMF Pursue Capital-Account Convertibility?", Essays in International Finance No. 207, Department of Economics, Princeton University, May 1998.

[11] Gourinchas, P.-O. and O. Jeanne (2006): "The Elusive Gains From International Financial Integration", Review of Economic Studies 73, 715-741. 
[12] Hall, R. E. and C.I. Jones (1999): "Why Do Some Countries Produce So Much More Output Per Worker Than Others?", Quarterly Journal of Economics Vol. 114 No.1, 83-116.

[13] Hoxha, I., S. Kalemli-Ozcan and D. Vollrath (2009): "How Big Are The Gains From International Financial Integration?" NBER Working Paper No. 14636.

[14] Kose, M. A., E. Prasad, K. Rogoff and S.-J. Wei (2009): "Financial Globalization: A Reappraisal", IMF Staff Papers Vol. 56 No.1, 8-62.

[15] Kose, M. A., E. Prasad and M. E. Terrones (2003): "Financial Integration and Macroeconomic Volatility", IMF Staff Papers Vol. 50 (Special Issue), 119-142.

[16] Lucas, R. E. Jr. (1990): "Why Doesn't Capital Flow from Rich to Poor Countries?", American Economic Review 80, 92-96.

[17] Pinto, P. M. (2005): "Does Partisanship Affect the Regulation of Foreign Investment?" Paper prepared for the Conference "The Political Economy of Regulating Multinational Corporations and Foreign Direct Investment," Pennsylvania State University, State College, October 14$15,2005$.

[18] Pinto, P. M. and S. M. Pinto (2008): "The Politics Of Investment Partisanship: And The Sectoral Allocation of Foreign Direct Investment", Economics $\&$ Politics Vol. 20 No. 2, 216-254.

[19] Prasad, E., R. Rajan and A. Subramanian (2006): "Patterns of International Capital Flows and Their Implications for Economic Development", in "Proceedings", Journal by Federal Reserve Bank of Kansas City, 119-158.

[20] Reinhardt, D., L. A. Ricci and T. Tressel (2010): "International Capital Flows and Development: Financial Openness Matters", IMF Working Paper No. 10/235.

[21] Schularick, M. (2006): "A Tale of Two 'Globalizations': Capital Flows from Rich to Poor in Two Eras of Global Finance", International Journal of Finance and Economics 11, 339-354. 


\section{A Appendix}

\section{A.1 Baseline scenario}

Solving the capitalist's budget constraint (4) forward and employing a transversality condition one obtains

$$
k_{t}^{c}=\sum_{i=0}^{\infty}\left(\frac{c_{t+i}^{c}}{\prod_{j=0}^{i} R_{t+j}}\right)
$$

Combining this with the re-arranged consumption Euler equation (expressed in terms of per-capita consumption)

$$
c_{t+i}^{c}=\beta^{i} \prod_{j=1}^{i} R_{t+j} c_{t}^{c}
$$

we get the following expression for the capital stock

$$
k_{t}^{c}=\sum_{i=0}^{\infty}\left(\frac{c_{t}^{c} \beta^{i} \prod_{j=1}^{i} R_{t+j}}{\prod_{j=0}^{i} R_{t+j}}\right)
$$

Simplification of the term in brackets in 11 finally yields

$$
\begin{aligned}
c_{t}^{c} & =(1-\beta) R_{t} k_{t}^{c} \\
k_{t+1}^{c} & =\beta R_{t} k_{t}^{c}
\end{aligned}
$$

\section{A.2 Scenario of free capital flows}

The stock of the domestic capitalist's assets after capital markets are opened, $a_{t}^{c}=k_{t}^{c}-d_{t}^{c}$, can be determined in an analogous way as the capital stock under autarky, equation (11). Using the optimality condition $R_{t+1}=R^{*}$ $\forall t>1$ and the no-Ponzi game condition $\lim _{T \rightarrow \infty} \frac{a_{t+T}^{c}}{R_{t} R^{*(T-1)}}=0$ we get

$$
a_{t}^{c}=\sum_{i=0}^{\infty}\left(\frac{c_{t+i}^{c}}{R_{t}\left(R^{*}\right)^{i}}\right)
$$


Using the transformed Euler equation $c_{t+i}^{c}=\beta^{i}\left(R^{*}\right)^{i} c_{t}^{c}$ yields

$$
a_{t}^{c}=\sum_{i=0}^{\infty}\left(\frac{\beta^{i} c_{t}^{c}\left(R^{*}\right)^{i}}{\left(R^{*}\right)^{i} R_{t}}\right)
$$

Finally, $\forall t>0$ we have

$$
\begin{aligned}
a_{t+1}^{c} & =\beta R^{*} a_{t}^{c} \\
c_{t}^{c} & =(1-\beta) R^{*} a_{t}^{c}
\end{aligned}
$$

while for $t=0$

$$
\begin{aligned}
a_{1}^{c} & =\beta R_{0} k_{0}^{c} \\
c_{0}^{c} & =(1-\beta) R_{0} k_{0}^{c}
\end{aligned}
$$

\section{A.3 The capitalist's welfare loss}

The capitalist's welfare loss is defined as

$$
W_{\text {loss }}^{c}=\sum_{t=0}^{\infty} \beta^{t} U\left(c_{t}^{c A}\right)-\sum_{t=0}^{\infty} \beta^{t} U\left(c_{t}^{c I}\right)
$$

Using (10), $c_{0}^{c A}=(1-\beta) R_{t} k_{0}^{c}$ and employing the assumption of log-utility, after re-arranging one gets

$$
W_{\text {loss }}^{c}=\sum_{t=0}^{\infty} \beta^{t} \ln \left(\frac{\prod_{j=1}^{t} R_{j}}{R^{* t}}\right)
$$

\section{A.4 The worker's welfare gain}

The worker's welfare gain is defined as

$$
W_{\text {gain }}^{w}=\sum_{t=0}^{\infty} \beta^{j} U\left(c_{t}^{w I}\right)-\sum_{j=0}^{\infty} \beta^{j} U\left(c_{t}^{w A}\right)
$$


Under the scenario of financial integration we have

$$
\begin{aligned}
U_{w}^{I} & =\sum_{t=0}^{\infty} \beta^{t} \ln \left(c_{t}^{w I}\right) \\
& =\ln \left((1-\alpha) A_{0}{\widetilde{k_{0}}}^{\alpha}\right)+\sum_{t=1}^{\infty} \beta^{t} \ln \left((1-\alpha) A_{t} \widetilde{k}^{* \alpha}\right)
\end{aligned}
$$

while under autarky

$$
\begin{aligned}
U_{w}^{A} & =\sum_{t=0}^{\infty} \beta^{t} \ln \left(c_{t}^{w A}\right) \\
& =\ln \left((1-\alpha) A_{0}{\widetilde{k_{0}}}^{\alpha}\right)+\sum_{t=1}^{\infty} \beta^{t} \ln \left((1-\alpha) A_{t}{\widetilde{k_{t}}}^{\alpha}\right)
\end{aligned}
$$

With these expressions, after re-arranging, we get for the welfare gain

$$
W_{\text {gain }}^{w}=\sum_{t=1}^{\infty} \beta^{t} \ln \left(\left(\frac{\widetilde{k}^{*}}{\widetilde{k}_{t}}\right)^{\alpha}\right)
$$

Given that under financial integration the capital stock per efficient unit of labor immediately jumps to its steady state level we can rewrite for $t>0$

$$
\widetilde{k}_{t+1}=\widetilde{k}_{t}=R^{*} \frac{\beta}{1+g^{*}} \widetilde{k}^{*}
$$

so that

$$
\widetilde{k}_{t+j}=\beta^{j}\left(R^{*}\right)^{j}\left(\frac{1}{1+g^{*}}\right)^{j} \widetilde{k^{*}}
$$

while under autarky

$$
\widetilde{k}_{t+j}=\left(\frac{1}{1+g^{*}}\right)^{j} \beta^{j} \prod_{i=0}^{j-1} R_{t+i} \widetilde{k}_{t}
$$

Plugging (13) and (14) into (12) and re-arranging we get

$$
W_{\text {gain }}^{w}=\sum_{t=1}^{\infty} \beta^{t} \ln \left(\left(\frac{\widetilde{k}^{*}\left(R^{*}\right)^{(t-1)}}{\widetilde{k}_{1} \prod_{j=1}^{t-1} R_{j}}\right)\right.
$$


Given that under autarky $k_{1}^{A}=A_{1} \widetilde{k}_{1}^{A}$ and under financial integration $k_{1}^{I}=$ $A_{1} \widetilde{k}^{* I}$ where the index $A(I)$ means autarky (financial integration) we finally have

$$
W_{\text {gain }}^{w}=\sum_{t=1}^{\infty} \beta^{t} \ln \left(\left(\frac{k_{1}^{I}}{k_{1}^{A}} \frac{\left(R^{*}\right)^{(t-1)}}{\prod_{j=1}^{t-1} R_{j}}\right)^{\alpha}\right)
$$

\section{A.5 The permanent capital owner's consumption loss}

Defining implicitly the capitalist's permanent consumption loss $\mu_{c}$ as

$$
\sum_{t=0}^{\infty} \beta^{t} \ln \left(c_{t}^{c A}-\mu_{c} c_{t}^{c A}\right)=U_{c}^{I}
$$

we can solve for $\mu_{c}$ as follows:

$$
\begin{aligned}
\sum_{t=0}^{\infty} \beta^{t} \ln \left(c_{t}^{c A}\right)+\sum_{t=0}^{\infty} \beta^{t} \ln \left(1-\mu_{c}\right) & =U_{c}^{I} \\
U_{c}^{A}+\sum_{t=0}^{\infty} \beta^{t} \ln \left(1-\mu_{c}\right) & =U_{c}^{I} \\
\mu_{c} & =1-\exp \left((1-\beta)\left(U_{c}^{I}-U_{c}^{A}\right)\right)
\end{aligned}
$$


Under the scenario of financial integration we have

$$
\begin{aligned}
U_{w}^{I} & =\sum_{t=0}^{\infty} \beta^{t} \ln \left(c_{t}^{w I}\right) \\
& =\ln \left((1-\alpha) A_{0}{\widetilde{k_{0}}}^{\alpha}\right)+\sum_{t=1}^{\infty} \beta^{t} \ln \left((1-\alpha) A_{t} \widetilde{k}^{* \alpha}\right)
\end{aligned}
$$

while under autarky

$$
\begin{aligned}
U_{w}^{A} & =\sum_{t=0}^{\infty} \beta^{t} \ln \left(c_{t}^{w A}\right) \\
& =\ln \left((1-\alpha) A_{0}{\widetilde{k_{0}}}^{\alpha}\right)+\sum_{t=1}^{\infty} \beta^{t} \ln \left((1-\alpha) A_{t}{\widetilde{k_{t}}}^{\alpha}\right)
\end{aligned}
$$

With these expressions, after re-arranging, we get for the welfare gain

$$
W_{\text {gain }}^{w}=\sum_{t=1}^{\infty} \beta^{t} \ln \left(\left(\frac{\widetilde{k}^{*}}{\widetilde{k}_{t}}\right)^{\alpha}\right)
$$

Given that under financial integration the capital stock per efficient unit of labor immediately jumps to its steady state level we can rewrite for $t>0$

$$
\widetilde{k}_{t+1}=\widetilde{k}_{t}=R^{*} \frac{\beta}{1+g^{*}} \widetilde{k}^{*}
$$

so that

$$
\widetilde{k}_{t+j}=\beta^{j}\left(R^{*}\right)^{j}\left(\frac{1}{1+g^{*}}\right)^{j} \widetilde{k^{*}}
$$

while under autarky

$$
\widetilde{k}_{t+j}=\left(\frac{1}{1+g^{*}}\right)^{j} \beta^{j} \prod_{i=0}^{j-1} R_{t+i} \widetilde{k}_{t}
$$

Plugging (15) and (16) into (14) and re-arranging we get

$$
W_{\text {gain }}^{w}=\sum_{t=1}^{\infty} \beta^{t} \ln \left(\left(\frac{\widetilde{k}^{*}\left(R^{*}\right)^{(t-1)}}{\widetilde{k}_{1} \prod_{j=1}^{t-1} R_{j}}\right)\right.
$$


Given that under autarky $k_{1}^{A}=A_{1} \widetilde{k}_{1}^{A}$ and under financial integration $k_{1}^{I}=$ $A_{1} \widetilde{k}^{* I}$ where the index $A(I)$ means autarky (financial integration) we finally have

$$
W_{\text {gain }}^{w}=\sum_{t=1}^{\infty} \beta^{t} \ln \left(\left(\frac{k_{1}^{I}}{k_{1}^{A}} \frac{\left(R^{*}\right)^{(t-1)}}{\prod_{j=1}^{t-1} R_{j}}\right)^{\alpha}\right)
$$

\section{A.5 The permanent capital owner's consumption loss}

Defining implicitly the capitalist's permanent consumption loss $\mu_{c}$ as

$$
\sum_{t=0}^{\infty} \beta^{t} \ln \left(c_{t}^{c A}-\mu_{c} c_{t}^{c A}\right)=U_{c}^{I}
$$

we can solve for $\mu_{c}$ as follows:

$$
\begin{aligned}
\sum_{t=0}^{\infty} \beta^{t} \ln \left(c_{t}^{c A}\right)+\sum_{t=0}^{\infty} \beta^{t} \ln \left(1-\mu_{c}\right) & =U_{c}^{I} \\
U_{c}^{A}+\sum_{t=0}^{\infty} \beta^{t} \ln \left(1-\mu_{c}\right) & =U_{c}^{I} \\
\mu_{c} & =1-\exp \left((1-\beta)\left(U_{c}^{I}-U_{c}^{A}\right)\right)
\end{aligned}
$$




\section{Diskussionsbeiträge \\ des Fachbereichs Wirtschaftswissenschaft \\ der Freien Universität Berlin}

2011

2011/1 NEHER, Frank

Markets Wanted - Expectation Overshooting in Transition

Economics

2011/2 KNOLL, Martin / Petra ZLOCZYSTI

The Good Governance Indicators of the Millennium Challenge

Account

Economics

2011/3 KAPPLER, Marcus / Helmut REISEN / Moritz SCHULARICK /

Edouard TURKISCH

The Macroeconomic Effects of Large Exchange Rate Appreciations Economics

2011/4 MÜLLER, Kai-Uwe / Viktor STEINER

Beschäftigungswirkungen von Lohnsubventionen und Mindestlöhnen Economics

2011/5 WRAGE, Markus / Anja TUSCHKE / Rudi K. F. BRESSER

The Influence of Social Capital on CEO Dismissal in Germany

Strategic Management

2011/6 BLAUFUS, Kay / Sebastian EICHFELDER / Jochen

HUNDSDOERFER

The hidden burden of the income tax

FACTS

2011/7 MUCHLINSKI, Elke

Die Rezeption der John Maynard Keynes Manuskripte von 1904 bis 1911

Economics

2011/8 FOSSEN, Frank M.

Personal bankcuptcy law, wealth and entrepreneurship - Theory and evidence from the introduction of a „fresh start“

Economics

2011/9 CALIENDO, Marco / Frank FOSSEN / Alexander KRITIKOS

Personality characteristics and the decision to become and stay self-employed

Economics 
2011/10 BACH, Stefan / Martin BEZNOSKA / Viktor STEINER

A Wealth Tax on the Rich to Bring Down Public Debt?

Economics

2011/11 HETSCHKO, Clemens / Andreas KNABE / Ronnie SCHÖB

Changing Identity: Retiring from Unemployment

Economics

2011/12 BÖRNER, Lars / Battista SEVERGNINI

Epidemic Trade

Economics

2011/13 SIELAFF, Christian

Steuerkomplexität und Arbeitsangebot - Eine experimentelle Analyse FACTS

2011/14 SCHÖB, Ronnie / Marcel THUM

Job Protection Renders Minimum Wages Less Harmful

Economics

2011/15 GLOCKER, Daniela / Viktor STEINER

Returns to Education across Europe

Economics

2011/16 CORNEO, Giacomo

A Note on the Taxation of Couples Under Income Uncertainty Economics

2011/17 ENGLER, Philipp / WULFF, Alexander

Opposition to Capital Market Opening

Economics 